\title{
Evaluation of the Hydrocarbon Potentials of shale exposures at Okpekpe in Edo North
}

\author{
Ogbamikhumi Alexander ${ }^{1} *$, Igbinigie Nosa Samuel ${ }^{1}$, Odokuma-Alonge Ovie ${ }^{1}$ \\ ${ }^{1}$ Department of Geology, faculty of Physical Sciences, University of Benin, Nigeria
}

* Corresponding author : alexander.ogbamikhumi@uniben.edu

Tel.: +2348032722203

Received: Oct 1, 2016. Accepted: Nov 20, 2019.

DOI: 10.25299/jgeet.2019.4.4.2807

\section{Abstract}

This study evaluates the source rock characteristics of rock exposures along a newly exposed road cut in Okpekpe. An integrated technique of organic geochemical analysis and biostratigraphy evaluation were adopted to determine the source rock quality, Maturation index, kerogen types, depositional environment andsediment age.

Results of organic geochemistry gave total organic carbon (TOC) value between 0.81 to 3.04 w.t\% (2.08wt.\% average) indicative of a good source potentials. The plot of Total Sulphur Content (TSC) against TOC suggests a transitional depositional environment for the samples while the plot of hydrogen index (HI) against oxygen index (OI) shows that the samples are capable of generating mixed type II/III kerogen.

Palynological analysis revealed that the basal section of the exposure is characterized by the occurrences of typical and moderately rich Late Cretaceous - Early Tertiary palynomorphs. While the upper section is poorly rich in palynomorph abundance but with spot occurrences. The palynomophs asssemlages is of Late Maastrichtian - Early Paleocene and the outcrop is characterized by the presence of terrestrial pollens and spores indicating a continental to transitional depositional environment, typical of the Mamu Formation of the Anambra Basin.

Keywords: Organic-Geochemistry, Biostratigraphy, Source-Rock, Okpekpe, Anambra-Basin

\section{Introduction}

Katz (1995) described source rock as fine grained argillaceous deposits, rich enough in organic matter and capable of generating hydrocarbon. Prospectivity for hydrocarbon is dependent on various factors such as the presence of viable structures and a viable petroleum system, of which the presence of source rock is a key component.

Understanding the characteristics of the source rock shed light on its quality and hydrocarbon generating potentials (Ogbamikhumi et al., 2017). In localities where the formation of the study source rock needed to be tied to regional geology, Biostratigraphy characteristics play a major role in age and environment of deposition determination, which will ultimately help in correlating the rock exposure to it corresponding regional equivalent when compared to literature.

Only few documented reports are available on this region of the Anambra Basin. (Edegbai and Emofurieta 2015; Ogbamikhumi and Igbinigie, 2017), Most recorded work of the Anambra basin are restricted to the center of the Basin (Burke et al., 1972; Ladipo, 1988; Nwajide and Reijers, 1996; Nton and Bankole, 2013; Ola and Adeoti 2017).

Hence the motivation behind this study; which intends to characterize the encountered shale exposures to understand its hydrocarbon generation potential and define its regional equivalent by comparing analytical result obtained with recorded literatures.
The study area is located in Okpekpe community, Edo North at coordinates $\mathrm{N} 07^{\circ} 11^{\prime} 02.0^{\prime \prime}$ and E006 ${ }^{\circ} 28^{\prime} 06.5^{\prime \prime}$. It is situated within the Anambra Basin, specifically at the Benin flank of the basin (Figure 1). Generally, the sediment of this region includes extension of the Ajali Formation, the transgressive Nkporo group and the regressive Coal measures of the late cretaceous sea (Nwajide, 2005).

\section{Materials and Methods}

Five outcrop samples were obtained from the study area and subjected to both organic geochemical analysis and Palynological evaluation after sample preparation in the laboratory. The slide preparation method for Palynological study was in accordance with standard methods as described in literature (Traverse, 1988; Wood et al., 1996).

A Frequency count of stratigraphically important forms was determined for each of the samples. Necessary photomicrographs of important structures and forms were taken using a digital camera attached to the microscope for detailed study and identification of the fossils forms and characteristic.

The organic geochemical evaluation technique adopted include: Turbidimetrically barium sulphate precipitate for total sulphur content determination (TSC), The Walkley Black Wet Oxidation method using a soxhlet extractor, for Total organic carbon (TOC) estimation and the Rock-Eval Pyrolysis technique. The Rock-Eval Pyrolysis technique is used for the anhydrous pyrolysis of source rocks that enables the chemical composition of kerogen, and hence its hydrocarbon potential to be determined (Espitalie 
et. al., 1985; Peters, 1986). Parameters estimated mathematically from results of the pyrolysis process for

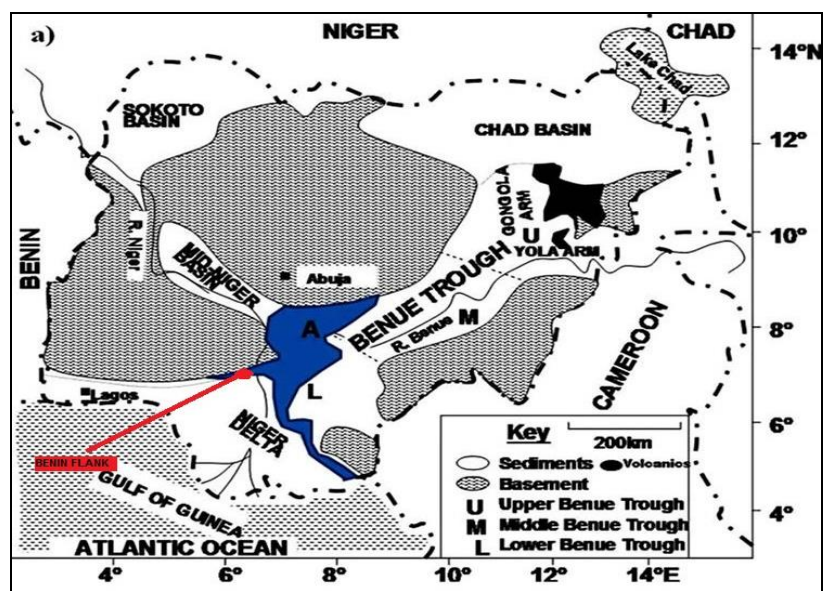

Fig. 1. Geological map of Nigeria showing the Anambra basin and the study area (Abubakar, 2014).

\section{Results}

The geochemical analysis results of the samples are presented in the table 1 . TOC is the total amount of insoluble organic material or kerogen present in the rock, and it is expressed as a percentage in weight (TOC wt.\%). It is a source quality index that qualifies a rock sample as either being a potential source of hydrocarbon or not.

TSC represent the total amount of sulphur in the sample. The sulphur content in a rock sample is associated with fauna abundant as we move from the continent to the deep marine. Therefore, it can be used as an index to predict the environment in which the sample was deposited.

The SOM represent the extractable organic constituent in the sample. S1 captures the free hydrocarbon constituent in the analyzed samples i.e the organic matter that has been completely transformed to hydrocarbon. $\mathrm{S} 2$ is defined by the generated hydrocarbon that are released by thermal cracking of nonvolatile constituent of organic matter, which give an insight to the potential amount of producible hydrocarbon in the rock if sediment burial and maturation continues.S3 is the total quantity of generated $\mathrm{CO} 2$, that account for the oxygen richness of kerogen, and is rely upon to estimate the oxygen index.

Tmax is the temperature at which the greatest amount of hydrocarbon is released from kerogen during the pyrolysis process. This happens at the top of S2 peak, and it is an index of sediment maturity, which is dependent on the kerogen type.

$\mathrm{HI}$ is the ratio of $\mathrm{S} 2$ hydrogen to TOC in grams. $\mathrm{HI}$ is a source rock hydrocarbon richness index. OI is the ratio of S3 hydrogen to Total organic carbon.

GP represent the total free hydrocarbon generated from pyrolysis of the samples and the existing hydrocarbon in the samples. PI represent the ratio of the free hydrocarbon to the potential hydrocarbon yield. This parameter is an index that account for organic matter evolution.

Table 1 Results of the Geochemical analysis

\begin{tabular}{|c|c|c|c|c|c|c|c|c|c|c|c|}
\hline Samples & TOC & $\mathrm{S} 1$ & $\mathrm{~S} 2$ & S3 & TSC & Tmax & GP & PI & $\mathrm{HI}$ & OI & SOM \\
\hline 1 & 1.82 & 0.29 & 3.37 & 0.91 & 0.36 & 424 & 3.66 & 0.08 & 185 & 50 & 1050 \\
\hline 2 & 3.04 & 0.56 & 12.82 & 1.25 & 0.39 & 417 & 13.38 & 0.04 & 422 & 41 & 1330 \\
\hline 3 & 2.44 & 0.32 & 3.34 & 1.43 & 0.67 & 418 & 3.66 & 0.09 & 137 & 59 & 1870 \\
\hline 4 & 0.81 & 0.08 & 0.25 & 1.09 & 0.81 & 470 & 0.33 & 0.24 & 31 & 135 & 2960 \\
\hline \multirow[t]{2}{*}{5} & 2.30 & 0.49 & 4.10 & 1.42 & 0.79 & 421 & 4.59 & 0.11 & 178 & 62 & 2840 \\
\hline & $\begin{array}{l}\text { S and } S \\
\text { ximum } \\
\text { tion Ind } \\
n \text { Index }\end{array}$ & $\begin{array}{l}\mathrm{I} \text { are in } \\
\text { peratur } \\
\mathrm{gCO} 2 / \mathrm{g}\end{array}$ & & $\begin{array}{l}\text { S1, } \\
\text { TOC } \\
\text { HI- } \\
\text { TSC }\end{array}$ & $\begin{array}{l}\text { Total } \mathrm{O} \text { and } \\
\text { drogen } \\
\text { otal Su }\end{array}$ & $\begin{array}{l}\text { re in } \mathrm{mg} \\
\mathrm{c} \text { Carbo } \\
\mathrm{r} \text { conten }\end{array}$ & $\begin{array}{l}\mathrm{SOl} \\
\mathrm{mgl} \\
\mathrm{Wt} \\
\mathrm{mgC}\end{array}$ & $\begin{array}{l}\text { oluble } \\
\text { - Milli } \\
\text { Jeight F } \\
\mathrm{g}-\mathrm{Mil}\end{array}$ & $\begin{array}{l}\text { anic } \\
\text { n Hyd } \\
\text { ent } \\
\text { am Car }\end{array}$ & lioxide & \\
\hline
\end{tabular}


Journal of Geoscience,

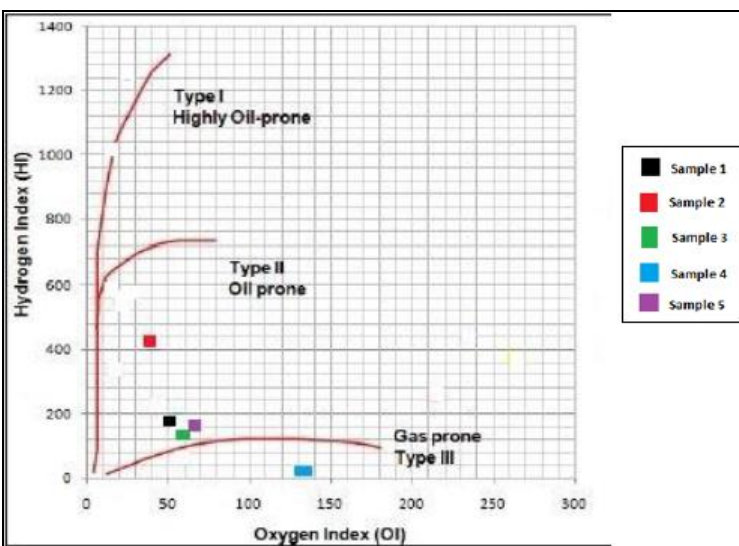

Fig 2. Hydrogen index versus Oxygen index plot showing the type of organic matter. modified from Van Krevelen diagram (after Akande, 2012)

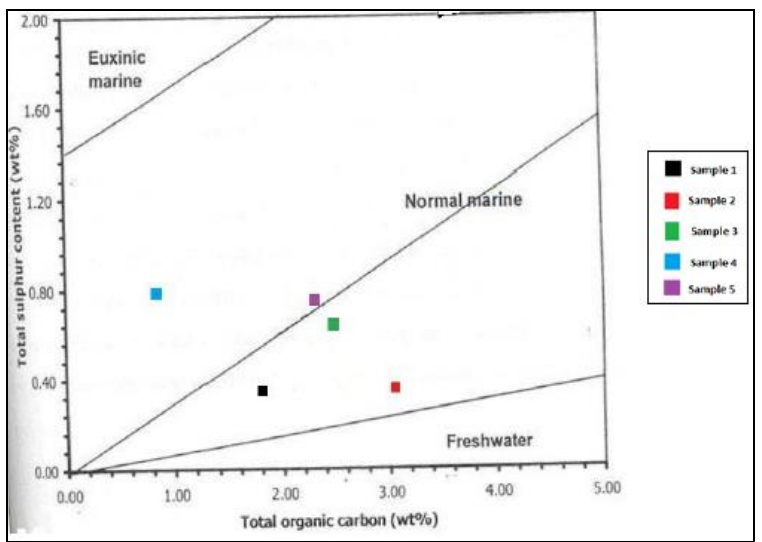

Fig 3. Plot of TSC against TOC indicating various aquatic conditions of deposition (modified from Leventhal, 1983)

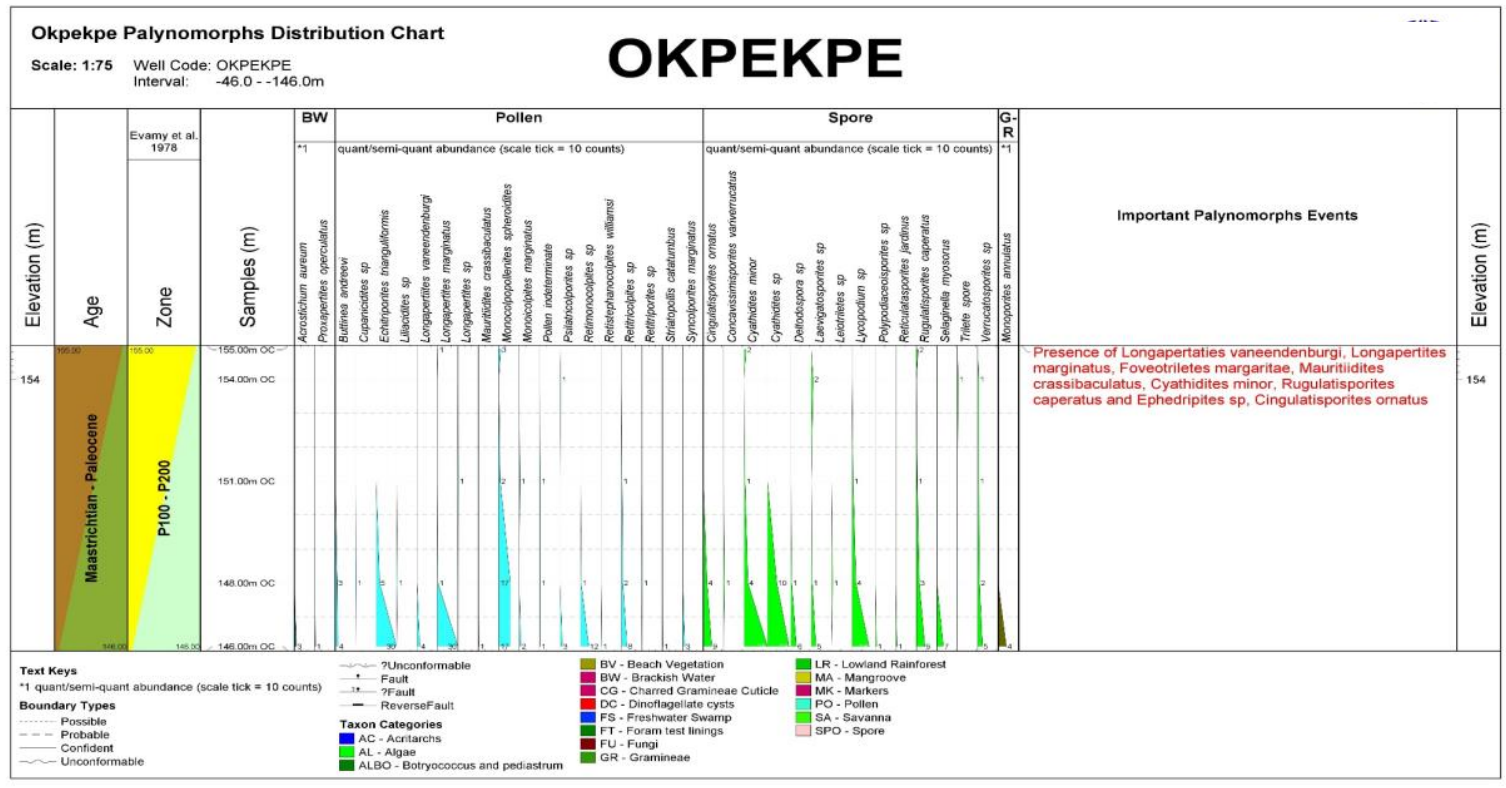

Hig 4. Palynomorphs Distribution Cnart

Table 2 Summary of Palynostratigraphic zonation, Age and Environment of deposition.

\begin{tabular}{|c|c|c|c|c|c|}
\hline Sample No & $\begin{array}{l}\text { Elevation } \\
\text { (m) }\end{array}$ & $\begin{array}{l}\text { Zonation } \\
\text { (After Evamy et al., } \\
\text { 1978) }\end{array}$ & Characteristics & Age & $\begin{array}{l}\text { Depositional } \\
\text { Environment }\end{array}$ \\
\hline $\begin{array}{l}5 \\
4 \\
3\end{array}$ & $\begin{array}{l}155 \\
154 \\
151\end{array}$ & Palynozone 200 & $\begin{array}{l}\text { Spot occurrences of } \\
\text { Cyathidites minor, } \\
\text { Rugulatisporites caperatus, } \\
\text { Lycopodium sp, } \\
\text { Monocolpollenites } \\
\text { sphaeroidites }\end{array}$ & Early Paleocene & \\
\hline $\begin{array}{l}2 \\
1\end{array}$ & $\begin{array}{l}148 \\
146\end{array}$ & Palynozone 100 & $\begin{array}{l}\text { Occurrence of Foveotriletes } \\
\text { margaritae, Proxapertites } \\
\text { operculatus, Longapertites } \\
\text { marginatus, Buttinia andreevi }\end{array}$ & Late Maastrichtian & Continental \\
\hline
\end{tabular}


The plot of hydrogen Index versus Oxygen Index is a graphical means of highlighting the hydrocarbon type the source rock is expected to generate (Figure 2). The Hydrogen Index is dependent on the kerogen type present in a source rock i.e the higher the hydrogen index, the greater the tendency for the source rock to yield oil and vice versa for gas.

Figure 3 present the graphical plot of Total Sulphur Content against Total Organic Carbon. This plot is a means of interpreting the possible environment of deposition of the analyzed rock sample.

The results of Palynological analysis is presented in Figure 4 and summarized in table 2 .

\section{Discussions}

\subsection{Source Quality and Kerogen type}

Tissot and Welte (1984) and Hunt (1979), proposed $0.5 \mathrm{wt} \%$ as the minimum threshold value for a rock to be regarded as a petroleum source rock. As presented in Table 2, the TOC of the samples ranges from 0.81 to 3.04 w.t $\%$ (2.08wt.\% average), which exceeds the threshold value of $0.5 \mathrm{wt} . \%$. This suggests that the samples are good to very good source rocks and is similar to report of earlier workers that study the source potentials of the Mamu Formation and the Nkporo Shales (Babatunde, 2010).

Source rocks genetic potential that is below $2 \mathrm{mgHC} / \mathrm{g}$ are indicative of minor oil content but with some potential gas, while those with genetic potential of $2-6 \mathrm{mgHC} / \mathrm{g}$ have some reasonable oil potential (Tissot and Welte, 1987; Akande et. al., 2005). The Genetic potential values for the samples ranges from 0.33 to $13.38 \mathrm{mgHC} / \mathrm{g}(5.12 \mathrm{mgHC} / \mathrm{g}$ average), which indicates that they have infinitesimal oil but some gas potential.

The kerogen type present in a source rock determines its Hydrogen Index. Many organisms contribute to the

organic matter present in petroleum source rocks and they differ in their organic matter and total hydrogen contents. The preserved organic matter exhibits parallel diversity that are further modified overtime into gas or oil (Dow, 1977). Laughrey (2009) proposed that source rocks with HI greater than $600 \mathrm{mgHC} / \mathrm{g}$ will generate oil, while those with HI between 200 and $600 \mathrm{mgHC} / \mathrm{g}$ will generate wet gas (oil and gas). Rocks with $\mathrm{HI}$ values between 50 and $200 \mathrm{mgHC} / \mathrm{g}$ will generate gas and those with $\mathrm{HI}$ values less than $50 \mathrm{mgHC} / \mathrm{g}$ are inert.

The HI value for the studied samples ranges from 31 to $422 \mathrm{mgHC} / \mathrm{g}$ (190.6 $\mathrm{mgHC} / \mathrm{g}$ average) suggesting that the source rock is gas and oil prone. The plot of $\mathrm{HI}$ against $\mathrm{OI}$ in the modified Van Krevelen diagram in figure 2, also reveals that studied samples are predominantly type III/II kerogen. This implies that the samples are majorly oil-gas prone source rocks and is similar to reports of Akaegbogbi (2000).

\subsection{Source Rock Maturation}

Maturation is the process of chemical change in sedimentary organic matter due to burial, i.e. the action of increasing temperature and pressure over geological time (Miles, 1989).

The concentration and distribution of the Hydrocarbon contained in a particular source depends on both the type of the organic matter and its degree of thermal maturation. Peter and Cassa (1994) proposed that source rocks with TMax values of less than $435 \mathrm{oC}$ are Immature, while those with Tmax value of between $435-470 \mathrm{oC}$ are Mature and those above $470 \mathrm{oC}$ are post mature.

For the studied samples, The value ranges from 417 to 4700C (430oC average). This suggests that majority of the samples are immature and are similar to the report of Ogala (2011) for the Maastrichtian Mamu Formation of the Anambra Basin.

\subsection{Paleo-environment Interpretation}

The paleo-depositional environment of a rock can be determined by the abundance of ancient life forms recoverable from sample analysis, believed to have thrived in the same environment where the rock was deposited.

From the Palynological evaluation results (Figure 4 and Table 2, The outcrop sediments were predominantly dominated by land derived pollens and spores. According to Schrank (1984), an assemblage of palynomorph with a high content of pollens and spores indicates a terrestrial influence and vice versa.

Based on this observation, the outcrop was characterized by the presence of terrestrial pollens and spores such as Longapertites vaneendenburgi, Foveotriletes margaritae, Echitriporites trianguliformis, Cingulatisporites ornatus, Erecipites sp., Longapertites sp., Liliacidites sp., Lycopodium sp, Cyathidites minor, Echitriporites trianguliformis, Cupaniedites sp indicates continental environment.

This depositional environment is also supported by the paucity of foraminiferal species over these samples. The nonrecovery of foraminifera is also attributable to the lithology of the samples, deposited in a continental environment where bottom conditions were not conducive for the preservation of foraminiferal species.

The cross plot of TSC versus TOC parameters derived from the organic geochemical analysis in figure 3, exclusively shows a normal marine depositional environment for the samples, which tends towards a terrestrial environment. Both results from palynological and geochemical analysis is suggestive of the proximal end of the transitional depositional environment for the studied samples.

\subsection{Biozonation and age determination}

From the results in Figure 4 and table 2, two palynozone were defined;

\subsubsection{Palynozone 100 / Assemblage Zone: III}

This zone was defined within the Intervals $145-148 \mathrm{~m}$. It is the oldest Assemblage Zone recognized in the analyzed portion of the outcrop.

The preponderance of typical Late Maastrichtian forms such as Syncolporites sp, Rugulatisporites caperatus, Foveotriletes margaritae, Proxapertites operculatus, Longapertites sp., Mauritidites crassibaculatusi, Longapertites marginatus, Buttinia andreevi, Longapertites vaneendenburgi, Monocolpites marginatus recovered within this section confirms this Assemblage Zone assignment which is dated Late Maastrichtian.

\subsubsection{Palynozone 200 / Assemblage Zone IV}

The zone is defined within the interval $148-155 \mathrm{~m}$. Recorded at interval are spot occurrences of Cyathidites minor, Rugulatisporites caperatus, Lycopodium sp, Monocolpollenites sphaeroidites, Monocolpites marginatus and Longapertites marginatus, suggest an Early Paleocene age.

The age assignment follows the informal Assemblage Zones classification of Palynozone 100-200 by Evamy et al (1978), this zone is equivalent to the Zone III- IV of Legoux (1978).

The studied sections of the outcrop ranges in age from Late Maastrichtian- Early Paleocene and the predominance of terrestrial pollen and spores, paucity of dinocysts and forams indicates that the paleo-depositional environment is Continental to transitional. This corresponds to the depositional environment established in literature of the Mamu Formation (Obaje, 2009). 


\section{Conclusion}

The results of organic geochemical and palynological evaluation of the source potentials of the studied exposure in Okpekpe revealed that the shales have a good to very good source potentials and are typically made of a type III/II kerogen constituent capable of generating gas and oil when attained maturation.

Both analysis results revealed that the rock was most likely deposited close to the terrestrial end of a transitional environment. Palynological evaluation showed that the studied rock exposure ranges in age from Late Maastrichtian- Early Paleocene. This was based on index spores, pollens and dinoflagellates. These include Longapertites marginatus, Cingulatisporites ornatus, Proxapertites cursus, Echitriporites trianguliformis, Cyathidites minor, Rugulatisporites caperatus, all of which are dated to be of Maastrichtian - Paleocene age which agrees with the age of the Mamu Formation in the Anambra basin

\section{References}

Abubakar, M.B., 2014. Petroleum Potentials of the Nigerian Benue Trough and Anambra Basin: A Regional Synthesis. Natural resources scientific research 5(1), 25-58.

Akaegbobi, I. M., Nwachukwu, J. I, Schmitt, M., 2000. Aromatic hydrocarbon distribution and calculation of oil and gas volumes in post-Santonian shale and coal, Anambra Basin, Nigeria In: Petroleum systems of South Atlantic margins. Amer.73, 233-245.

Akande, S.O., Ojo, O.J., Erdtmann, B.D., Hetenyi, M., 2005. Paleoenvironments, Organic Petrology and Rock - Eval Studies on Source Rock Facies of the Lower Maastrichtian Patti Formation, Southern Bida Basin, Nigeria. Journal of African Earth Sciences 41, 394-406.

Akande, G.W., 2012. Evaluation of Hydrocarbon Generation Potential of the Mesozoic Organic-Rich Rocks Using TOC Content and Rock-Eval Pyrolysis Techniques. Geosciences 2(6), 164-169.

Babatunde, O.L., 2010. The main oil source formations of the Anambra Basin, Southeastern Nigeria. AAPG International Convention \& Exhibition, September, 1215 .

Burke, K.C., Dessauvagie, T.F.J., Whiteman, A.J., 1972. Geological history of the Benue valley and adjacent areas, University of Ibadan Press, Nigeria.

Dow, W. G., Kamata, H., Suizu, M., 1992. The art of maturity modeling: Part 1. Finding a satisfactory geological model. AAPG Bulletin 76, $31-46$.

Edegbai, A. J., Emofurieta, W. O., 2015. Preliminary assessment of source rock potential and palynofacies analysis of Maastrichtian dark shale, SW Anambra. Ife Journal of Science 17(1), 131-139.

Espitalie, J., Deroo, G., Marquis, F., 1985. Rock Eval pyrolysis and its Applications. Institute Francais du Petrole, France.

Hunt, J. M., 1979. Petroleum Geochemistry and Geology:W. H. Freeman, San Francisco, USA.

Katz, B., 1995. Petroleum Source Rocks: Springer-Verlag, Houston, USA.
Ladipo, K.O., 1988. Paleogeography, sedimentation and tectonics of Upper Cretaceous Anambra Basin, southeastern Nigeria. Journal of African Earth Sciences $7(5 / 6), 865-871$.

Laughrey, C. D., 2009. Applied Petroleum Geology and Geochemistry for thermogenic shale gas evaluation,Weatherford Laboratories, Golden, Colorado, USA.

Legoux,O., 1978. Quelques espèces e pollen caractéristiques du Neogene du Nigeria. Bull. Cent. Rech. Explor. Elf Aquit. 2(2), 265-317

Leventhal, J.S., 1983. An interpretation of carbon and sulfur relationships in Black Sea sediments as indicators of environments of deposition. Geochimica et Cosmochimica Acta 47, 133-137.

Miles, J.A., 1989. Illustrated glossary of petroleum geochemistry. Oxford Univ. Press. U.K.

Nton, M. E., Bankole, S. A., 2013. Sedimentological characteristics, provenance and hydrocarbon Potential of post Santonian sediments in Anambra Basin, southeastern Nigeria: RMZ-Materials and Geoenvironment Journal 60(1), 47-66.

Nwajide, C. S., Reijers, T. J. A., 1996. Geology of the southern Anambra Basin. selected chapters on Geology, SPDC, Warri:133-148.

Nwajide C. S., 2005. Anambra Basin of Nigeria: Synoptic Basin Analysis as a Basis for Evaluating its Hydrocarbon Prospectivity. In Hydrocarbon Potentials of the Anambra Basin; Geology, Geochemistry and Geohistory Perspectives. Great AP Express Publ., Ltd., Nigeria.

Obaje N.G., 2009. The Benue Trough Geology and Mineral Resources of Nigeria. Springer, Berlin, Heidelberg, 57 68.

Ogala, J. E., 2011. Hydrocarbon potentials of The Upper Cretaceous coal and shale units in the Anambra Basin, Southeastern Nigeria. Petroleum and Coal 53(1),35 44.

Ogbamikhumi, A., Igbinigie, N. S., Aiworo, O. E., 2017. Organic Geochemical Evaluation for Source Rock Potentials of Mamu Formation Exposed at The Benin Flank of Anambra Basin. Indo-Iranian Journal of Scientific Research (IIJSR) 1(1), 41-45.

Ogbamikhumi,A., Igbinigie, N.S., 2017. Palynological and Organic Geochemical Studies for SourceRock Characterisation and Evaluation of Mamu Formation in the Benin Flank of the Anambra Basin, The International Journal of Engineering and Science (IJES) 6(10), 55-60.

Ola, P. S., Adeoti, B., 2017. Palynomorphs of the First DownHole Shale Occurrence in Three Contiguous Basins in Nigeria: Implication on the K-Pg Boundary. Geosciences Research, 2(3).

Peters, K. E., 1986. Guidelines for evaluating petroleum source rock using programmed pyrolysis.American Association of Petroleum Geologists, Bulletin. 70(3), $318-329$

Peters, K. E., Cassa, M. R., 1994. Applied Source Rock Geochemistry. In: The Petroleum System - From 
Source to Trap AAPG Memoir, 60, Tulsa, OK, 93-117 Shrank, E., 1984. Organic geochemical and palynological studies of Dekhia shales profile (Late Cretaceous) in southern Egypt. Berliner geowiss, Abh., $50,189-207$

Tissot, B., Welte, D., 1984. Petroleum Formation and Occurrence (2nd Ed.): Springer-Verlag, Berlin.

Traverse, A., 1988. Palaeopalynology: Unwin Hyman, London.
Wood, G.D., Gabriel, A.M., Lawson, J.C., 1996. Palynological techniques-processing and microscopy. In: Palynology: principles and applications. American Association of Stratigraphic Palynologists Foundation, Dallas 1, 29-50.

(c) 2016 Journal of Geoscience, Engineering, Environment and Technology. All rights reserved. This is an open access article distributed under the terms of the CC BY-SA License (http://creativecommons.org/licenses/by-sa/4.0/). 